\title{
THE QUÉBEC CASE: IS THERE A SECRET?
}

\author{
Mona-Josée Gagnon \\ Professeure, \\ Département de sociologie, \\ Université de Montréal, \\ Montréal, Québec, Canada
}

\author{
Thomas Collombat \\ Ph.D. Candidate, \\ Department of Political Science, \\ Carleton University, \\ Ottawa, Ontario, Canada
}

Q uébec trade unions can boast about a unionization rate of $39.7 \%$, which is the highest in Canada (average 31.2\%) and much higher than the mean American rate. Nevertheless, this enviable situation at best has stabilized, and for the worst has started to decline, if decimals are to be taken up seriously. But let us consider the actual situation and its more recent developments in the legal framework and institutional arrangements. As those are the result of social relations, in which the strength of trade unions, as well as their audience and legitimacy play a significant role, it is very difficult, and clearly out of the scope of this article, to screen all of the favourable factors that contributed to Quebec's positive labour relations situation. One key factor which, to trade union eyes, remains problematic, is the declining rate in the private sector $(26.2 \%)$, as the traditionally unionised manufacturing jobs disappear and trade unions hardly make up with successes in the private tertiary sector.

In this article, we will put forward the three factors that, as far as the unions are concerned, may not have been decisive but were surely important in this relative success in unionization. We intentionally focus on subjects that are at discussion in the U.S. Employee Free Choice Act. And, not surprisingly, these are the same matters which Québec trade unions have asked for or are fighting to keep, considering their instrumental role to the process of unionization. First is the basis on which union recognition is obtained - i.e. a ballot or majority union card sign-up. Second is the scheme of arbitration of the first union contract. And lastly stands the creation of a Commission des relations du travail (CRT) in 2001 (operational in 2003), an administrative body of a new type, with an encompassing mandate covering all the juridical apparatus related to work but also dedicated to the acceleration of procedures related to requests of union accreditation.

\section{THE SECRET BALLOT}

In Québec, union recognition based on card signing has been in place since the 1944 Loi sur les relations ouvrières (Labour Relations Act, which preceded the first Labour Code, or Code du travail, which was subsequently adopted in 1964). Although the law initially required that $60 \%$ of the employees signed cards for recognition to be granted, the threshold was quickly lowered to $50 \%$. A 
union can still request recognition with less than $50 \%$ plus one of the cards signed $(35 \%$ to $50 \%)$. In this case a ballot is then organized to check if the majority of workers agree to be represented by the union. It has always been very rare that a union would request recognition with less than a majority of the cards signed, as the odds of success are quite slim. A ballot can also be organised if an employer can argue about union misdemeanours or convincingly express a doubt on the claim of an existing majority, such a situation being a reflection of the openness of the system to employer's contests.

We could almost say that the "automatic" secret ballot is a non-subject in Québec (and even in the industrial relations textbooks). Trade unions certainly do not favour this procedure even though it is accessible. But employers' organizations have been lobbying in favour of it on a regular basis, and individual employers (e.g. Wal-Mart) use all the opportunities to argue that Quebec's mode of unionisation is not "democratic" because no ballot is held. So the labour movement regularly stands up for the status quo, as a preventive mean of defence. The argument is not original, but Québec trade unionists have experienced both with-and-without ballot procedures of accreditation - and on the basis of experience they prefer the existing system.

Indeed, Québec unions have seen how, when a vote is organized, employers use the period leading to the ballot to resort to the worst union busting tactics. Firing of union activists, compulsory anti-union meetings, sudden changes in the organization of work, and threats to close the shop should the union be allowed are among the most common manoeuvres used to discourage workers to cast their ballots in favour of the union. Of course, most of these practices are illegal, but proving it in court is extremely difficult, most notably because the union is not yet in the workplace and thus has a restricted access to the information necessary to plead the cause, and also because the workers are, precisely, afraid of the consequences their involvement could have on their job.

At the core of the labour movement argument is the idea that, in this context, voting does not equal democracy. Contrary to the most elementary rules of modern democracy, these compulsory votes are neither free nor transparent. The parties involved - the union and the employer - do not have equal access to the "electors" - the workers - as the employer (and his representatives) remains the sole master in "his" company. In the capitalist system, the corporation represents one of the last non-democratic spaces of society where, thanks to the sacrosanct "management right", arbitrary decisions can be taken without even consulting the concerned individuals. Having a union in a workplace does not make it a democratic space, but it certainly diminishes the ground on which arbitrary decisions can be taken. Much more than a question of wages, facilitating the presence of unions in workplaces is acknowledging their democratizing function. Recognizing a union on the base of card signing is therefore more, not less, democratic, than automatically requiring a vote. 


\section{THE ARBITRATION OF THE FIRST CONTRACT}

In Québec, it is possible to ask for the arbitration of a first collective agreement, if the initial negotiations seem to go nowhere. When this disposition was adopted in 1977 (following the British Columbia experience), unions considered it as an important victory, something like the final touch in the process of trade union recognition. Of course, companies where unions decide to use this procedure are precisely the ones in which the employers fought vigorously to avoid the union. After all, trade unions prefer to negotiate, even harshly, rather than putting the fate of their first contract in the hands of an arbitrator. Still, after having seen many new unions disappear following months of union busting and employer refusal to negotiate, the labour movement thought very positively of this new possibility, which also constituted an additional argument for convincing hesitant workers in an organizing campaign.

The actual feelings may be a bit different nowadays in union circles. No union representative would support abolishing the first contract arbitration scheme, which can permit a new union to survive and go on to negotiate a second contract. But the appreciation of their practice among unions today is more subtle, especially considering the hard experience of the recent first contract arbitration in a Wal-Mart store. The role of an arbitrator in such circumstances is to define the "market of reference" and to rule on comparable compensation work conditions. This can be quite a simple operation in substantially unionized and homogenous sectors (e.g. municipal employees), but it becomes very tricky in less unionized and heterogeneous sectors. Should one compare Wal-Mart to a grocery store, to a department store, or even a hardware store? So the road is opened to months of harsh and technically-loaded discussions, with management experts and academics called on by both sides. For sure, without this procedure of arbitration of the first contract, the only unionized Wal-Mart store in North America would probably have lost its union recognition. Still the experience was painful for the workers involved, and painful and costly for the union.

\section{THE CREATION OF A NEW MECHANISM (CRT)}

The creation of a newly conceived Commission des relations de travail (2001) seems much more consensual. Important parts of the labour movement, namely the Québec Federation of Labour, had long asked for such a commission. An official enquiry commission on work (Commission consultative sur le travail), of which some prominent labour leaders were members, had made the creation of a new administrative structure a priority of its report in 1985. So the 2001 legislative modifications were long over-due. Before these changes, there were two levels of decision as far as requests for union recognition were concerned. The first level of decision (the Commissaires généraux du travail) could always be contested on one or another basis (design of the bargaining unit, number of cards, violation of the Labour Code, etc.) and appeals were then made to the 
second level, the Tribunal du travail. Employers unwilling to accept a union in their premises made extensive use of this procedure, resulting in long delays to certification or, even worse, the disappearance of the case altogether due to personnel movements and employers' harassment. That is notably what happened to an important request concerning a MacDonald's restaurant in Montréal earlier this decade.

The new CRT is now the one and only level where union recognition can be granted, even if an employer contests the design of the bargaining unit. The Commission has jurisdiction over all laws concerning labour relations and is autonomous from the Ministry of Labour. Unions can now realistically expect a conclusive answer with only short delays. The overall situation has improved notably due to the CRT and labour relations (at least concerning union recognition) have become less litigious. Some industrial relations commentators even consider that the ordinary tribunals have now become redundant in workrelated conflicts. Nevertheless, a thoroughly anti-union employer can still develop ways to lengthen the recognition process, though it is less easy than before.

\section{IS THE SECRET IN THE LAW?}

Although the Québec experience is encouraging for unions operating in other jurisdictions where the juridical apparatus is more hostile to labour, we think that the existing apparatus can still be improved. We do not know of any Québec union organizer who finds that his job is easy, and this is especially true in the private service sector. As stated by one academic and former union leader, Jean Gérin-Lajoie (2004), one could almost consider that if an industry is unionized at a $12 \%$ rate, then an attempt at unionization in a company of this particular industry has twelve chances in one hundred to succeed. This is surely a pessimistic view, considering the very low rate of unionization in sectors where the workforce is more numerous. But the obstacles to unionization remain daunting, even in Quebec.

Beyond legal considerations, there is a growing consciousness within the labour movement that efforts must be made to enhance the arguments for unionization. If, in the manufacturing sector, the argument of significantly better wages was and is still relevant, this is not the case in other industries. Across the whole labour market, the greatest advantages to unionization are based in the limitation of the employer's powers, the introduction of genuine equity, employment security, and more generally in the democratization of the workplace.

\section{REFERENCES}

Fédération des travailleurs et travailleuses du Québec, 2007, Document d'information pour les résolutions 39 et 40, 28e Congrès, Québec. 
103 Just Labour: A Canadian Journal of Work and Society - V. 15 - Special Edition - Nov. 09

Gagnon, Robert P. and al. 2008, Le droit du travail du Québec, Cowansville, Éditions Yvan Blais.

Gérin-Lajoie, Jean, 2004, Les relations du travail au Québec, Montréal, Gaétan Morin éditeur. 